\title{
Methodology for determining the elemental composition, as well as energy and ignition properties of the low-sulfur marine fuels
}

ARTICLE INFO

Received: 3 July 2021

Revised: 17 August 2021

Accepted: 24 August 2021

Available online: 25 August 2021
The key metrological issue of substance and energy balance in research engines is the precise determination of the elemental composition of the applied fuel and its net calorific value. This makes it possible to calculate the amount of heat brought with the fuel into the combustion chamber, as well as the amount and gas composition of the exhaust. However, to fully assess the energy quality of the fuel used, its ignition properties should also be estimated. They determine the combustion kinetics and, consequently, the course of gas pressure alterations and heat release in the cylinder, which have a direct impact on the indicated power and thermal efficiency of the engine.

This article presents the methodology for carrying out this type of laboratory tests and their representative results concerning six different low-sulfur marine fuels used to feed marine engines at present. The considerations focus mainly on measurement technology, as well as the measuring apparatus applied today. Additionally some existing metrological difficulties that might be met were shortly described. The laboratory tests in question stand for the first stage of the program of testing a new kind of low-sulfur marine fuels in real operating conditions of a diesel engine, which was carried out at the Department of Ship Power Plants of the Gdańsk University of Technology.

Key words: marine low-sulfur fuels, laboratory tests, examination means and methods

This is an open access article under the CC BY license (http://creativecommons.org/licenses/BY/4.0/)

\section{Introduction}

The knowledge of the elemental composition of a marine fuel, apart from the excess air ratio, enables the quantity and gas composition of engine exhaust gases to be determined based on the known stoichiometric relationships $[10,11]$. It also enables an approximate estimation of the fuel's net calorific value, which is a measure of its chemical energy. The elemental composition of liquid fuels is determined by the gas chromatography through the mass fractions of combustible elements: carbon $\mathrm{C}$, hydrogen $\mathrm{H}$ and sulfur S, as well as the ballast: oxygen $\mathrm{O}$, nitrogen $\mathrm{N}$ (the shares of ash $\mathrm{P}$ and moisture $\mathrm{W}$ in the ballast are usually omitted) [2,6].

The basis for assessing the energy quality of marine fuels is the amount of heat released in the combustion process, which determines a temperature of the marine engine exhaust, as well as its thermal efficiency. The basic evaluation parameter is then the net calorific value of the fuel, determined experimentally, based on the direct measurement of the heat of combustion (the gross calorific value) in a calorimetric bomb [17].

The ignition properties of marine fuels are characterized by the self-ignition delay, i.e. the period that elapses from the while of fuel injection into the engine combustion chamber (the beginning of the fuel sprayer's needle rising) to the while of the flame initiation in its gas space. The quantification of the ignition properties of marine fuels is carried out in two ways, depending on their kind:

- for distillate fuels - based on the cetane number $(\mathrm{CN})$, determined during tests on a standardized research engine [14-16],

- for residual, traditional and modified fuels - on the basis of calculations of the aromatic hydrocarbon content index called shortly also with abbreviation as CCAI (Cal- culated Carbon Aromaticity Index), determined from an empirical calculation formula, taking into account fuel viscosity and density [1].

\section{Elemental analysis of the fuel composition}

The basic method of elemental analysis of marine fuels is gas chromatography $[5,12,13]$. It is worked out with the application of fully automated digital chromatographs, in which the entire analytical process, from introducing a representative fuel sample to determining the mass fractions of the main chemical elements in the fuel, takes just several minutes - Fig.1.

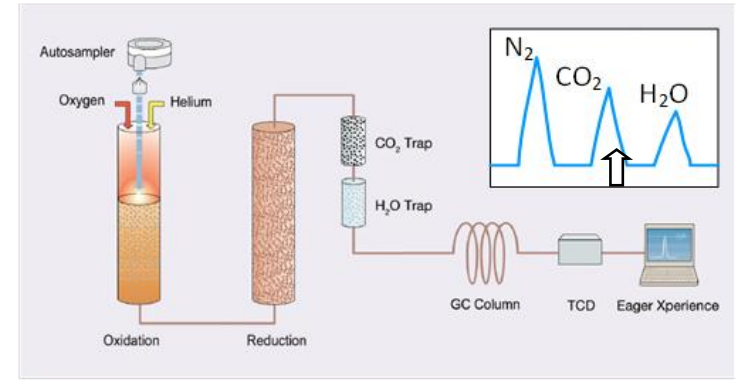

Fig. 1. Schematic diagram of a gas chromatography for the determination of the mass fractions of carbon $\mathrm{C}$, hydrogen $\mathrm{H}$ and nitrogen $\mathrm{N}$ in a liquid fuel [19]

The starting point of the measurement procedure is the tested fuel sample's weighing, rinsing with atmospheric nitrogen, and then its explosive combustion in an atmosphere with high temperature and high content of purified oxygen (99.998\%). As a result of the complete conversion of liquid fuel to gaseous form, various chemical compounds are produced, resulting from the oxidation of its individual constituent elements. In the subsequent stages of the measu- 
rement procedure, it is necessary to extract from the combustion products only: elemental nitrogen $\mathrm{N}_{2}$, water vapor $\mathrm{H}_{2} \mathrm{O}$ and carbon dioxide $\mathrm{CO}_{2}$, before their sequential introduction into the stream of the carrier gas (most often helium $\mathrm{He}$, with a purity of $99.995 \%$ ) to the measuring cell of the chromatograph detector.

In the first stage, this is carried out by the catalytic interaction of calcium oxide $\mathrm{CaO}$ (to reduce sulfur oxides $\mathrm{SO}_{\mathrm{x}}$ ), copper oxide $\mathrm{CuO}$ (to bind excess oxygen, reduce all gaseous carbon compounds $\mathrm{CH}_{4}, \mathrm{CO}$ to carbon dioxide $\mathrm{CO}_{2}$ and nitrogen oxides $\mathrm{NO}_{\mathrm{x}}$ to elemental nitrogen $\mathrm{N}_{2}$ ). However, in the second stage - by sequential capture (absorption $^{1}$ ) of carbon dioxide $\mathrm{CO}_{2}$ (sodium hydroxide, $\mathrm{NaOH}$ ) and water vapor $\mathrm{H}_{2} \mathrm{O}$ (magnesium perchlorate, $\mathrm{Mg}\left(\mathrm{ClO}_{4}\right)_{2}$ ). The basis for the quantification of the gaseous components in the stream of the carrier gas is the chromatogram, defined as a series of sharp peaks of $\mathrm{N}_{2}, \mathrm{CO}_{2}, \mathrm{H}_{2} \mathrm{O}$, the height of which corresponds to the instantaneous concentration of the chemical compound emerging from the reduction column. The area under each peak can be converted to the total concentration of a given chemical in the total gas mixture. For the mathematical processing of the recorded time courses of the individual gas components concentration, specialized computer programming is applied, where the derivatives determining the maximums of individual peaks (retention times ${ }^{2}$ ), as well as their beginnings and ends are determined by numerical methods. In the next step of the calculations, the corresponding surface areas are sequentially determined by numerical integration within the peak beginning and peak end. As a result, it is possible to automatically determine the percentage by mass of the basic chemical elements $\mathrm{C}, \mathrm{H}, \mathrm{N}$ in the sample of the tested fuel, from the relationship defined in the ASTM Standard: D5291 [12].

The $\mathrm{N}_{2}$ nitrogen concentration measuring cell is most often based on the Thermal Conductivity Detector (TCD), while for $\mathrm{CO}_{2}$ carbon dioxide and for $\mathrm{H}_{2} \mathrm{O}$ water vapor - on the Infrared detector (IR) or a Flame Photometric Detector (FPD) [2].

An important supplement to the elemental analysis of the elemental composition of the fuel in the range of $\mathrm{C}, \mathrm{H}$, $\mathrm{N}$ is the determination of the mass fractions of sulfur $\mathrm{S}$ and oxygen $\mathrm{O}-$ Fig. 2 . In the first case (Fig. 2a), the fuel sample is weighed in a silver container and introduced into the process reactor.

Combustion gases are transferred in a helium stream to a copper-filled layer, then passed through a water trap $\left(\mathrm{H}_{2} \mathrm{O}\right)$, a short chromatograph column (GC), and finally the sulfur content is measured with a flame photometric detector $(\mathrm{FPD})^{3}$.

\footnotetext{
${ }^{1}$ In heated so-called chemical traps, which absorb carbon dioxide $\mathrm{CO}_{2}$ and water vapor $\mathrm{H}_{2} \mathrm{O}$ at low (room) temperatures. Only elemental nitrogen $\mathrm{N}_{2}$ is passed through. As the pools are heated to a specific desorption temperature, the previously captured $\mathrm{CO}_{2}$ and then $\mathrm{H}_{2} \mathrm{O}$ are directed to the chromatograph detector.

${ }^{2}$ The time it takes for a given chemical to pass through the entire measuring cell of the chromatograph.

${ }^{3}$ Other measurement techniques are also used, e.g. the method of thermal conductivity (TCD) or fluorescence X-ray spectrometry:
}

a)

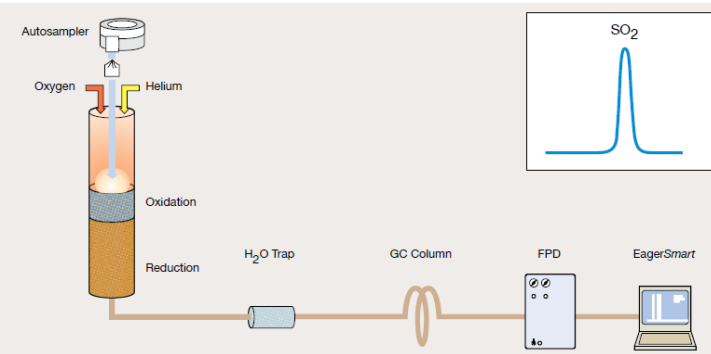

b)

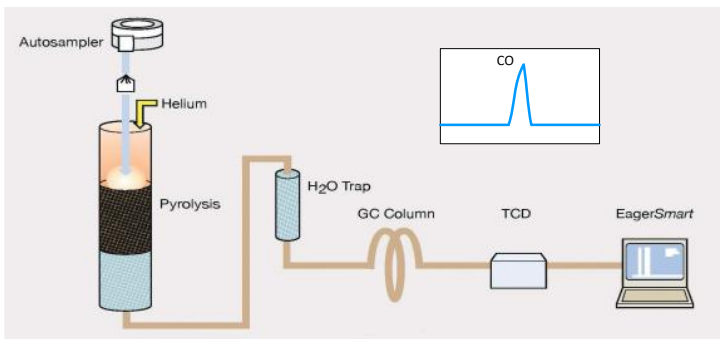

Fig. 2. Schematic diagram of the gas chromatography in the scope of determining the mass fractions, respectively: a) sulfur $\mathrm{S}$, b) oxygen $\mathrm{O}$, in a liquid fuel [19]

In the case of determining the oxygen content in the fuel (Fig. 2b), the chromatograph system operates in the pyrolysis mode. After the sample is weighed in a silver container, it is introduced into a pyrolysis reactor containing nickelcoated carbon (at approximately $1060^{\circ} \mathrm{C}$ ), under an inert gas atmosphere (e.g. helium He). The oxygen in the sample, in combination with the carbon, forms carbon monoxide $\mathrm{CO}$, which is then chromatographically separated from other combustion products (pyrolysis gases) and detected by a thermal conductivity detector (TCD).

In order to determine the elemental composition of the considered low-sulfur marine fuels, they were tested in the chemical laboratory of Grupa LOTOS S.A., using the VarioMacro CHN and Trace SN Cube analyzers of the German company Elementar Analysensysteme GmbH. Determination of the mass fraction of carbon, hydrogen, nitrogen and sulfur is fully automatic, using a specialized computer software. The results of the elemental analysis of the tested fuels are summarized in Table 1.

Table 1. Measurement results of elemental composition as well as energy and ignition properties of the considered low-sulfur marine fuels

\begin{tabular}{|l|c|c|c|c|c|c|}
\hline \multicolumn{1}{|c|}{ PARAMETER } & MGO & MDO & $\begin{array}{c}\text { RMD } \\
80 / \mathrm{L}\end{array}$ & $\begin{array}{c}\text { RMD } \\
80 / \mathrm{S}\end{array}$ & $\begin{array}{c}\text { RME } \\
180\end{array}$ & $\begin{array}{c}\text { RMG } \\
380\end{array}$ \\
\hline The content of carbon $C, \% \mathrm{~m} / \mathrm{m}$ & 86,26 & 86,63 & 86,14 & 86,54 & 86,12 & 86,10 \\
\hline $\begin{array}{l}\text { The content of hydrogen } H, \% \\
\mathrm{~m} / \mathrm{m}\end{array}$ & 11,10 & 11,20 & 11,72 & 11,75 & 11,80 & 11,90 \\
\hline The content of nitrogen $N, \% \mathrm{~m} / \mathrm{m}$ & 0,05 & 0,04 & 0,027 & 0,02 & 0,02 & 0,02 \\
\hline The content of sulfur $S, \% \mathrm{~m} / \mathrm{m}$ & 0,09 & 0,008 & 0,028 & 0,10 & 0,01 & 0,01 \\
\hline Gross calorific value $[\mathrm{MJ} / \mathrm{kg}]$ & 46,20 & 45,68 & 46,01 & 45,41 & 46,19 & 46,03 \\
\hline Net calorific value $[\mathrm{MJ} / \mathrm{kg}]$ & 43,23 & 42,70 & 43,04 & 42,44 & 43,20 & 43,08 \\
\hline $\begin{array}{l}\text { Cetane number }(\mathrm{CN}) / \\
/ \text { Calculated carbon aromaticity } \\
\text { index }(\mathrm{CCAI})\end{array}$ & 57,2 & 51 & 755 & 791 & 750 & 747 \\
\hline Density at $15^{\circ} \mathrm{C}, \mathrm{kg} / \mathrm{m}^{3}$ & 827,1 & 820 & 872,7 & 885 & 878,7 & 884,5 \\
\hline $\begin{array}{l}\text { Kinematic viscosity at } 40^{\circ} \mathrm{C} \text { (dist.) } \\
/ 50^{\circ} \mathrm{C} \text { (res.), } \mathrm{mm} m^{2} / \mathrm{s}\end{array}$ & 2,99 & 2,37 & 77,83 & 16,48 & 165,30 & 308 \\
\hline
\end{tabular}

Energy Dispersive X-ray Fluorescence (ED XRF) or Wavelength Dispersive X-ray Fluorescence (WD XRF) $[6,12]$. 
Even slight differences in the mass fractions of the main chemical elements in the fuel supply have got a significant impact on the thermal efficiency of the engine. As shown by the results of the conducted engine tests its alteration range value for the six tested low-sulfur marine fuels was $3.21 \%[7,8]$.

\section{Fuel's net calorific value}

The basis for determining the net calorific value of marine fuels are calorimetric measurements of the amount of heat released $\mathrm{Q}_{\mathrm{w}}$ in the isochoric combustion process, which is related to the mass of the tested fuel sample $m_{p}$ [17]. The measurement technology consists in its complete combustion in an open crucible of the calorimetric bomb in the oxygen atmosphere with a constant pressure of $3.0 \mathrm{MPa}$ and registration of the water temperature increase in the calorimetric vessel $\Delta \mathrm{T}_{\mathrm{K}}=\mathrm{T}_{\mathrm{k}}-\mathrm{T}_{\mathrm{p}}{ }^{4}$ (Fig. 3). Then the appropriate corrections are determined, taking into account: a heat exchange with the environment $T_{\text {ot }}$ (from the average temperature increase and decrease in the measurement periods, respectively: A and C - by means of the so-called Bunt's formula [11]), as well as the heat released during the combustion of the ignition wire $\mathrm{Q}_{\mathrm{e}}$.
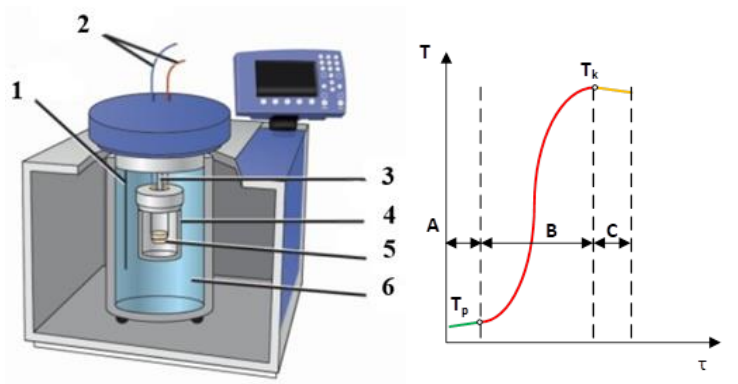

Fig. 3. Schematic diagram of the pressure calorimeter, as well as the calorimetric curve of water temperature variability during the determination of the fuel heat of combustion: $\mathrm{A}, \mathrm{B}, \mathrm{C}-$ characteristic measurement periods, respectively: initial, main and final $(\mathrm{A} \approx \mathrm{B}), 1$ - thermometer, 2 electrodes: insulated and with ignition wire, 3 - tubes: oxygen inlet and exhaust outlet, 4 - calorimetric bomb, 5 - crucible, 6 - water jacket [20]

From the determined calorimetric diagram, the gross calorific value $\mathrm{W}_{\mathrm{g}}$ is determined, and then - the net calorific value of the fuel $\mathrm{W}_{\mathrm{d}}$ is calculated, from the following formulas:

$$
\begin{gathered}
\mathrm{W}_{\mathrm{g}}=\frac{\mathrm{Q}_{\mathrm{w}}-\mathrm{Q}_{\mathrm{e}}}{\mathrm{m}_{\mathrm{p}}} \\
\mathrm{Q}_{\mathrm{w}}=\mathrm{C}_{\mathrm{k}} \cdot\left(\Delta \mathrm{T}_{\mathrm{k}}+\mathrm{T}_{\mathrm{ot}}\right) \\
\mathrm{Q}_{\mathrm{e}}=\mathrm{q}_{\mathrm{e}} \cdot\left(\mathrm{m}_{\mathrm{e} 1}-\mathrm{m}_{\mathrm{e} 2}\right) \\
\mathrm{W}_{\mathrm{d}}=\mathrm{W}_{\mathrm{g}}-\mathrm{r}_{\mathrm{p}} \cdot(8,94 \cdot \mathrm{H}+\mathrm{W})
\end{gathered}
$$

where: $C_{k}-$ calorimeter heat capacity (the calorimeter's constant $)^{5}, \mathrm{~m}_{\mathrm{e} 1}, \mathrm{~m}_{\mathrm{e} 2}-$ the mass of the ignition wire, respectively: before and after combustion, $\mathrm{q}_{\mathrm{e}}$ - combustion heat of the ignition wire, $6740,7 \mathrm{~kJ} / \mathrm{kg}, \mathrm{r}_{\mathrm{p}}$ - heat of water vaporiza-

\footnotetext{
${ }^{4}$ As a rule, the temperature increase $\Delta \mathrm{TK}$, determined with an accuracy of $10^{-4} \mathrm{~K}$, does not exceed $3 \mathrm{~K}$.

${ }^{5} \mathrm{It}$ is determined by means of benzoic acid (heat of combustion at $15^{\circ} \mathrm{C}$ and pressure of $3.0 \mathrm{MPa}$ equals $26433 \mathrm{~kJ} / \mathrm{kg}$ ) as the international thermochemical standard.
}

tion under standard conditions $\left(25^{\circ} \mathrm{C}\right)$, per $1 \%(\mathrm{~m} / \mathrm{m})$ of water contained in the tested fuel, $2442 \mathrm{~kJ} / \mathrm{kg}, 8.94$ - conversion ratio of hydrogen content into water.

In order to estimate the energy properties of the considered marine fuels, their gross calorific values were measured and their net calorific values were calculated. The experimentally determined net calorific value of the fuel enables a precise calculation of the amount of chemical energy entered into a combustion chamber of the tested engine. It represents an input value for further analyzes of the effectiveness of the working process carried out in the research engine. In order to obtain the most reliable results, the net calorific value of the marine fuels, in question, was measured by two independent institutions: the laboratory of the Department of Chemical Apparatus and Mechanical Engineering, Faculty of Chemistry, Gdańsk University of Technology, and the fuel laboratory of the LOTOS SA Group (Polish oil company).

The measurements carried out at the Gdańsk University of Technology were conducted with the IKA C200 type calorimeter [www.ika.com]. This is one of the most popular versions of calorimeters made by the German manufacturer IKA WERKE GmbH, which was designed and built for schools, technical, universities and industrial laboratories, etc., where the number of measurements is relatively small.

In turn, for measurements of the gross calorific values of the same fuels in the LOTOS laboratory, a different, newer and much more technologically advanced version of the calorimeter, from the same manufacturer, was applied IKA C6000 [www.ika.com].

An additional purpose of the laboratory tests carried out was the preliminary quantitative and qualitative estimation of the residual products after the combustion of the fuel sample in the calorimetric bomb crucible - Fig. 4.
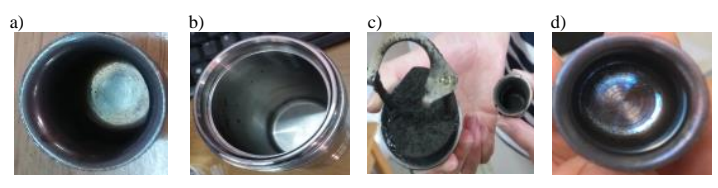

Fig. 4. Calorimetric bomb crucibles with residues of combustion products: a) MDO (Gdańsk University of Technology laboratory), b) RMD 80/S (Gdańsk University of Technology laboratory), c) RMG 380 (Gdańsk University of Technology laboratory), d) RMG 380 (LOTOS laboratory)

This gives some idea of what might be expected in the combustion chamber of the test engine after the application of a new kind of the feed fuel. As shown in Fig. 4c, in the case of RMG 380 fuel, the amount of carbon deposits remaining in the crucible was disqualifying, and in addition, despite repeated attempts (also with benzoic acid support), it was not possible to determine its net calorific value. Initially, it was thought that the fuel was heavily contaminated. However, its recleaning in a centrifuge did not bring the expected results.

The situation became clear only during the tests of the same fuel in the LOTOS laboratory, where the pressure of oxygen delivered to the calorimetric bomb was nearly twice as high. On the other hand, the amount of carbon deposits in the calorimetric bomb crucible after the conducted study was negligible - Fig. $4 \mathrm{~d}$. This means that the combustion of 
the fuel sample in the calorimeter was complete, contrary to the test carried out in the laboratory of the Gdańsk University of Technology.

Finally, the net calorific values of the investigated marine fuels, which are summarized in Table 1, were taken for further energy analyzes of the research engine [7, 8].

\section{Cetane number - CCAI Index}

In order to determine the cetane number $(\mathrm{CN})$ of distillate fuels, unified ${ }^{6}$, single-cylinder, four-stroke CFR F5 compression-ignition engines with indirect fuel injection into the pre-combustion chamber ${ }^{7}$ are used [3, 13-15]. Such a design solution of the test engine allows a minimisation of the fuel self-ignition delay, bringing the combustion process closer to isochoric heat supply in the pre-combustion chamber, with adjustable capacity (in the range of 6.69$76.52 \mathrm{~cm}^{3}$ ) and isobaric heat supply in the gas space above the piston (main combustion chamber), with a much larger displacement of $611.75 \mathrm{~cm}^{3}$. Both chambers are connected with a narrow (14 $\mathrm{mm}$ diameter) turbulence channel, which on the one hand provides favorable conditions for testing the combustion process in the pre-chamber (dynamics of pressure alterations, heat release and self-ignition capacity of the tested fuel), and on the other hand - minimizes mechanical and thermal loads in the main combustion chamber directly coupled to the piston-crank system. Moreover, very favorable conditions are obtained in the pre-combustion chamber for the fuel's complete combustion, despite the application of a simple (reliable) pintle injector. The engine is also less sensitive to the combustion of the fuels having lower self-ignition capacity. Unfortunately, this takes place at the expense of a significantly reduced efficiency of the working process being carried out, mainly due to the hydraulic losses of the return flow of the working medium through the connecting channel between the chambers, as well as the increased loss of heat discharged by the cooling medium from the walls of the extended combustion chamber.

Within the CFR F5 engine a non-standard system for regulating the geometric parameters of the working space and the injection system in motion is applied. It allows testing the self-ignition properties of the fuel to determine its cetane number in accordance with the ASTM D613-10a standard [14]. The adjustable capacity of the precombustion chamber enables smooth alterations of the compression ratio from 8:1 to $36: 1$ to achieve stable (knock-free) combustion, with the normative values of the fuel injection parameters, as follows: fuel injection advance

\footnotetext{
${ }^{6}$ The only supplier of this type of engines, recognized by fuel and internal combustion engine manufacturers, is the American company Dresser Waukesha. Interestingly, the design of the CFR F5 engine used to determine the cetane number of distillate fuels has remained practically unchanged since its production started in 1930. This is evidenced by, for example, the traditional (as for today's times, even archaic) micrometric knobs used in the control system of the pre-combustion chamber capacity, as well as the injection advance angle and fuel dose. On the other hand, it is also a great advantage of such a research tool, taking into account the repeatability of results obtained for almost 100 years.

7 This type of diesel engine solutions are not currently used.
}

angle $\alpha_{\mathrm{ww}}=13 \pm 0.2^{\circ} \mathrm{CA}^{8}$, self-ignition delay angle $\alpha_{\mathrm{osz}}=$ $13 \pm 0.2^{\circ} \mathrm{CA}^{9}$ and fuel dose for 1 work cycle corresponding to the volumetric flow rate $\dot{\mathrm{V}}_{\text {fuel }}=13 \pm 0.2 \mathrm{~cm}^{3} / \mathrm{min}^{10}$, as a function of the crankshaft rotation angle of the engine. Fuel injection parameters are adjusted while the engine is running (Fig. 5) by rotating the injection pump plunger with a fixed beginning and variable fuel injection end (fuel dose adjustment) and the injection pump camshaft relative to the engine crankshaft (adjustment of the fuel injection advance angle).

a)
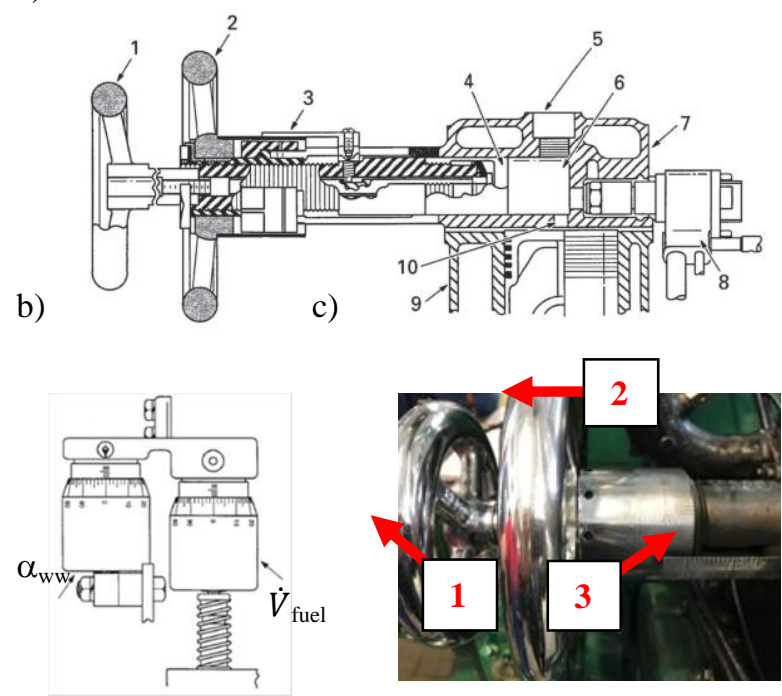

Fig. 5. Components of the CFR F5 test engine's control system: a) cylinder head assembly with adjustment of the pre-combustion chamber capacity, b) micrometric knobs of the mechanism for changing the injection advance angle $\alpha_{w w}$ and fuel dose $\dot{V}_{\text {fuel }}$, c) adjustment knobs for the compression ratio $\varepsilon$ of the engine: 1 - compression piston rod knob, 2 - piston rod position locking knob, 3 - micrometric scale of piston rod position, 4 compression adjustment piston rod, 5 - indicator channel, 6 - prechamber, 7 - cylinder head, 8 - fuel injector, 9 - cylinder, 10 - connection (turbulence) channel [18]

The fuel tests are carried out at the steady crankshaft rotational speed $\mathrm{n}=900 \pm 9 \mathrm{rpm}$, temperature and pressure of the lubricating oil, respectively: $\mathrm{t}_{\mathrm{ol}}=57 \pm 8^{\circ} \mathrm{C}$ and $\mathrm{p}_{\mathrm{ol}}=$ 0.175-0.210 MPa, temperature of the engine and fuel injector cooling medium, respectively: $\mathrm{t}_{\mathrm{ch}}=100 \pm 2^{\circ} \mathrm{C}$ and $\mathrm{t}_{\mathrm{chW}}=$ $38 \pm 3^{\circ} \mathrm{C}$, as well as the intake air temperature, raised to $\mathrm{t}_{\text {air }}=$ $65.5 \pm 0.5^{\circ} \mathrm{C}^{11}$. The ignition properties of distillate fuels are evaluated by determining their cetane numbers, taking into account the cetane numbers of reference fuels with a slightly lower and higher cetane number ${ }^{12}$. The highest cetane numbers have paraffinic hydrocarbons with a large number

\footnotetext{
${ }^{8}$ The fuel injection angle is accurately measured with the injector needle stroke sensor.

${ }^{9}$ The fuel self-ignition delay angle is determined by the gas pressure transducer installed in the cylinder head (item 5 in Fig. 5a).

${ }^{10}$ Determined by the volumetric method from fuel gauges.

${ }^{11}$ This is another element differentiating the test diesel engine in relation to standard diesel engines, this time in the context of external working conditions (combustion).

${ }^{12}$ The indicative $\mathrm{CN}$ value of the tested fuel should be predetermined.
} 
of carbon atoms, having long, straight chains of chemical bonds. Aromatic hydrocarbons have the lowest cetane numbers. The applied reference fuels stand for mixtures of hexadecane (also called cetane, $\mathrm{C}_{16} \mathrm{H}_{34}$ ), with $\mathrm{CN}=100$ and 1-methylnaphthalene (also called $\alpha$-methylnaphthalene, $\left.\mathrm{C}_{11} \mathrm{H}_{10}\right)^{13}$, with $\mathrm{CN}=0$.

The ASTM D613-10a and PN-EN ISO 5165 standards very precisely describe the methodology of fuel examinations by means of the CFR F5 test engine. After its start-up and bringing to a steady state, the following standard settings are entered:

1. Fuel doses per cycle (Fig. 5b),

2. Injection advance angle (Fig. 5b),

3. Self-ignition delay angle (item 1 in Fig. 5a,c), and then the position of the piston rod for regulating the engine compression ratio is read on the micrometric scale (item 3 in Fig. 5a,c).

When the tested fuel reaches the same self-ignition delay angle as the mixture of two basic reference fuels, its cetane number is determined by volume from the percentage of cetane and heptamethylone in the reference fuel blends, as follows:

$$
\mathrm{CN}=\mathrm{CN}_{\mathrm{n}}+\left(\frac{\mathrm{m}-\mathrm{m}_{\mathrm{n}}}{\mathrm{m}_{\mathrm{w}}-\mathrm{m}_{\mathrm{n}}}\right) \cdot\left(\mathrm{CN}_{\mathrm{w}}-\mathrm{CN}_{\mathrm{n}}\right)
$$

where: $\mathrm{CN}$ - the cetane number of the tested fuel, $\mathrm{CN}_{\mathrm{n}}-$ the cetane number of the reference fuel mixture with the lower $\mathrm{CN}$ value, $\mathrm{CN}_{\mathrm{w}}$ - the cetane number of the reference fuel mixture with the higher $\mathrm{CN}$ value, $\mathrm{m}, \mathrm{m}_{\mathrm{n}}, \mathrm{m}_{\mathrm{w}}$ - readings from the micrometric scale of the compression adjustment knob for, respectively: tested fuel, reference fuel mixture with a lower $\mathrm{CN}$ value and reference fuel with a higher $\mathrm{CN}$ value.

The self-ignition delay is also influenced by the technical condition of the fuel injector (in particular its sprayer), as well as the cylinder working space [4]. For this reason, the degree of delamination $\Delta \alpha_{\mathrm{OSZ}}$ of the characteristic $\alpha_{\mathrm{osz}}=$ $\mathrm{f}(\mathrm{CN})^{14}$ should be periodically checked, using a mixture of reference fuels with a known cetane number - Fig. 6 .

In the first series of measurements, the reference fuel mixture with the cetane number $\mathrm{CN}=30$ should be used, for which the self-ignition delay angle is set to $13.0^{\circ} \mathrm{CA}$, by means of the compression ratio adjustment knob (while maintaining the standard values of other regulatory parameters). In the next 3-4 measurement series, with the usage of reference fuel mixtures with a slightly higher cetane number (by about 4-5), the values of the self-ignition delay angle are read, while maintaining the standard values of the fuel flow rate $-13 \mathrm{~cm}^{3} / \mathrm{min}$ and injection advance angle $13^{\circ} \mathrm{CA}$, but without interfering with the compression ratio of the engine.

${ }^{13}$ In 1962 it was replaced with heptamethyloneate (also called isocetane or $\mathrm{HMN}, \mathrm{C}_{16} \mathrm{H}_{34}$ ), with a cetane number $\mathrm{CN}=15$, due to better stability of the oxidation process, easier storage, greater availability and lower purchase price. In this case, the cetane number scale $\mathrm{CN}=\%$ cetane $+0.15 \%$ isocetane. Currently, these fuels are used interchangeably, provided that there are ensured safe storage conditions of the methylnaphthalene.

${ }^{14}$ This type of test engine profiles should be determined immediately after its implementation into operation, treating it as reference material for further comparative analyzes ("finger print")

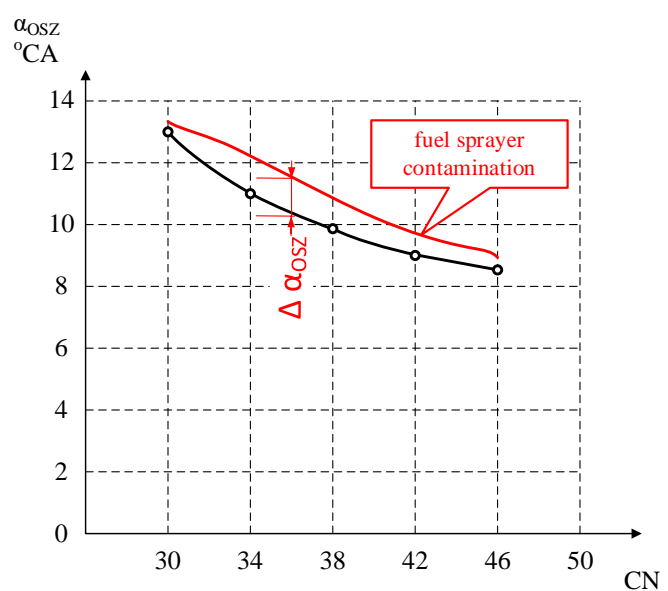

Fig. 6. Characteristics of the fuel self-ignition delay in the CFR F5 test engine as a function of the cetane number $[4,14,18]$

While the precise determination of the self-ignition delay of distillate fuels stands for a very well-known and controlled issue, the determination of this parameter for residual fuels might still pose significant metrological difficulties. The basic diagnostic parameter is then the so-called Calculated Carbon Aromaticity Index (CCAI) determined by the analytical method, based on the known values of density and kinematic viscosity of the tested fuel:

$$
\begin{aligned}
\mathrm{CCAI}= & \mathrm{e}-140.7 \cdot \log [\log (v+0.85)]-80.6- \\
& -483.5 \cdot \log [(\mathrm{t}+273) / 273]
\end{aligned}
$$

or in a simplified form (for a viscosity specified at $50^{\circ} \mathrm{C}$ ):

$$
\mathrm{CCAI}=\mathrm{\varrho}-141 \cdot \log [\log (v+0.85)]-81
$$

where: $\rho$ - fuel density at $15^{\circ} \mathrm{C}, \mathrm{kg} / \mathrm{m}^{3}, v$ - fuel kinetic viscosity, $\mathrm{mm}^{2} / \mathrm{s}(\mathrm{cSt}), \mathrm{t}-$ temperature at which the fuel viscosity was determined, ${ }^{\circ} \mathrm{C}$.

As can be easily noticed, the above empirical equations usually giving values in the range $720-870$, do not take into account the elemental composition of the fuel, and thus its energy properties. For this reason, fuels with a similar CCAI value may differ significantly in terms of selfignition ability. When interpreting the CCAI index, the rule is that the higher the CCAI value, the greater the selfignition delay, the greater the intensity of the pressure increase in the cylinder and the combustion temperature, at a much higher value of the maximum combustion pressure angle. This shifts the working process to the expansion stroke, which results in a decrease in the thermal efficiency of the engine (heat supply in the cycle is isobaric - with an increasing volume of the working medium above the piston moving towards the BDC), as well as its mechanical and thermal overload. For the above mentioned reasons, the maximum value of the CCAI index is limited to the ISO $8217: 2012$ "HFO specification" standard to the level of 860 . When the CCAI exceeds $860^{15}$, it means that some

\footnotetext{
${ }^{15}$ In turn, the delay of ignition of distillate fuels characterized by the cetane number, according to the ISO 8217-2005 standard, should be at least: 35 - for MDO and 40 - for MGO. In the Polish standard for diesel oils, regardless of their application, there is a minimum cetane number of 51 .
} 
combustion problems may occur. Studies by engine manufacturers indicate that the combustion problems caused by fuels with high CCAI can be reduced by avoiding the engine running at part load [1]. Therefore, it is suggested that in such a situation, if possible, the engine load should be kept above $50 \%$, listening simultaneously for the characteristic acoustic effects of knocking combustion.

According to equation (6), the highest values of the CCAI index are a characteristic feature of high-density, low-viscosity residual fuels - Table 1 .

The mutual relations of the indicators characterizing the self-ignition capability of marine distillate fuels $(\mathrm{CN})$ and residual fuels (CCAI) in the context of their impact on the functioning the marine engine are shown in Fig. 7.

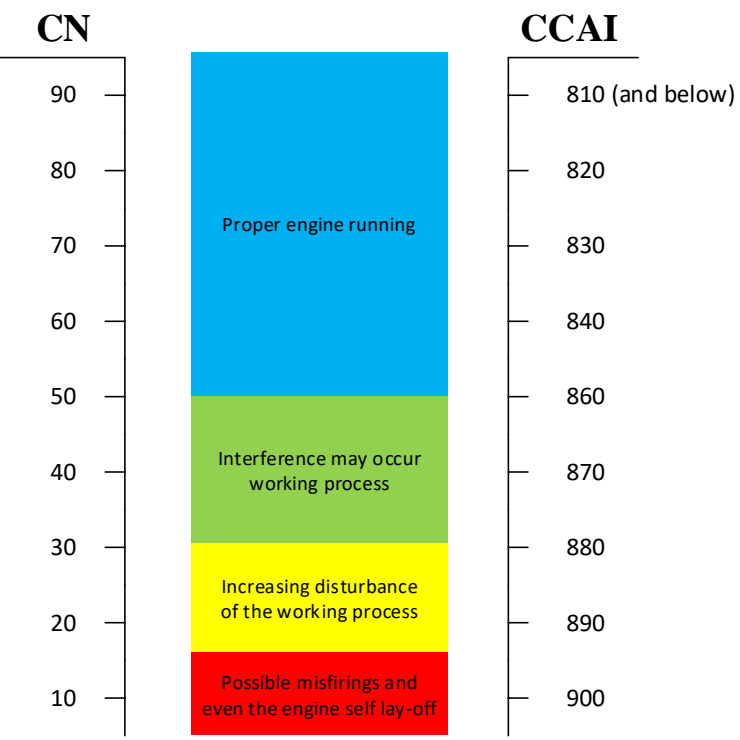

Fig. 7. Nomogram for the estimation of an impact of the self-ignition capacity indicators for marine fuels: distillate $(\mathrm{CN})$ and residual $(\mathrm{CCAI})$ on the functioning a marine engine

The delay in self-ignition of marine fuel is determined by the simultaneous impact of many factors, which result not only from its elemental composition and physicalchemical properties, but also from the applied design (and technical condition) of the functional systems of the engine fed with them, especially the combustion chamber, as well as the fuel and air fed system (injection and turbocharging unit). The shorter self-ignition delay, the smaller the injection timing, easier start-up and higher engine efficiency, thus lower fuel consumption. It also means a lower com- bustion pressure increase in the cylinders and, as a result, less mechanical and thermal loads carried during engine operation.

The main factors influencing the self-ignition capability of low-sulfur marine fuels can be ranked in the following order:

- cetane number $(\mathrm{CN})$ - for distillate fuels or the Calculated Carbon Aromatic Index (CCAI) - for residual fuels,

- air temperature and pressure in the cylinder space at the fuel injection beginning, accuracy and homogeneity of fuel dose atomization (injection pressure),

- air swirl in the combustion chamber (mixing fuel particles with air),

- subjecting fuel to physical (heating) and chemical (partial oxidation) treatment before self-ignition.

\section{Remarks and final conclusions}

On the basis of the obtained results of laboratory tests of elemental composition, as well as energy and ignition properties of the tested low-sulfur marine fuels, the following general conclusions can be formulated:

1. The characteristics of the technology for determining the net calorific value of marine fuels presented in this article for the precise estimation of the performance and energy efficiency of the research engine powered by them shows that it may cause certain metrological difficulties, especially when such thermochemical tests are performed occasionally. For this reason, additionally taking into account the need to ensure high accuracy of the engine energy calculations made on their basis, they should be commissioned to commercial laboratories, carrying out even several dozen fuel analyzes per day. Attention has been also paid to the possibility of preliminary, qualitative and quantitative, estimation of the combustion products of the tested fuel sample in the calorimetric bomb crucible, prior to its entering into the research engine fuel fed system.

2. Since the delay of self-ignition of residual fuels, determined by the value of the Calculated Carbon Aromatic Index (CCAI), may vary quite significantly, depending on their viscosity and density, in order to achieve the optimal conditions of the fuel combustion process in a CI engine, it may be necessary to adjust the injection advance angle (even by $3-6^{\circ} \mathrm{CA}$ ). Such operational recommendations are formulated after the completion of engine examinations of the tested fuel, mainly on the basis of a comparative analysis of developed indicator diagrams [9].

\section{Bibliography}

[1] ARMAS, I.P., VALENCIA, F.A. Ignition quality of residual fuel oils. Journal of Maritime Research. 2005, II(3), 77-96.

[2] BOCZKAJ, G., KAMIŃSKI, M. Gas chromatography with selective detection in analytics of sulfur and nitrogen volatile compounds. Camera separatoria. 2011, 3(1), 51-67.

[3] DYBICH, K. Zasada metody oznaczania liczby cetanowej próbek paliw silnikowych na stanowisku badawczym z silnikiem Dresser Waukesha CFR (USA). Nafta-Gaz. 2012, 1, 84-87.

[4] DYBICH, K. Problemy eksploatacyjne silników badawczych CFR Waukesha. Nafta-Gaz. 2011, 6, 417-420.
[5] GROB, R.L., BARRY, E.F. Modern practice of gas chromatography. 4th edition, John Wiley \& Sons Inc. New Jersey 2004.

[6] JĘDRYCHOWSKA, S., WIECZOREK, A. Analiza wielopierwiastkowa środków smarowych z wykorzystaniem techniki spektrometrii fluorescencji rentgenowskiej z dyspersją fali. Nafta-Gaz. 2013, 6, 476-485.

[7] KORCZEWSKI, Z. et al. Analiza wpływu właściwości paliw żeglugowych na charakterystykę energetyczną silnika Diesla, niezawodność jego pracy i zużycie części. Praca n-b nr 4600009272 (zleceniodawca - LOTOS Group S.A.), Politechnika Gdańska, Gdańsk 2019. 
[8] KORCZEWSKI, Z. et al. Metoda oceny skutków ekologicznych, energetycznych i niezawodnościowych stosowania modyfikowanych paliw okrętowych do zasilania silników Diesla w warunkach rzeczywistych. Praca n-b nr RX10/2017 współfinansowana przez wojewódzki Fundusz Ochrony Środowiska i Gospodarki Morskiej w Gdańsku. Politechnika Gdańska, Gdańsk 2019.

[9] KORCZEWSKI, Z. Diagnostyka eksploatacyjna okrętowych silników spalinowych - tłokowych i turbinowych. Wybrane zagadnienia. Wydawnictwo Politechniki Gdańskiej, Gdańsk 2017.

[10] WIŚNIEWSKI, S. Pomiary temperatury w badaniach silników i urządzeń cieplnych. Wydawnictwa NaukowoTechniczne, Warszawa 1983.

[11] WIŚNIEWSKI, S. Termodynamika techniczna. Wydawnictwa Naukowo-Techniczne, Warszawa 2005.

[12] ASTM D5291-16 Standard test method for instrumental determination of carbon, hydrogen and nitrogen in petroleum products and lubricants.

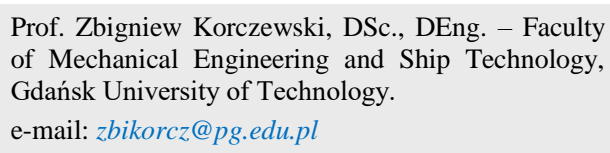

[13] ASTM D2622-16 Standard test method for-sulfur in petroleum products by wavelength dispersive X-ray fluorescence spectrometry.

[14] ASTM. D613-10a Standard test method for cetane number of diesel fuel oil; ASTM International: West Conshohocken.

[15] PN-EN ISO 5165:1998 Przetwory naftowe - oznaczanie właściwości zapłonowych olejów napędowych - metoda silnikowa oznaczania liczby cetanowej.

[16] PN-EN ISO 5165:2003 Przetwory naftowe oznaczanie właściwości zapłonowych olejów napędowych - metoda silnikowa oznaczania liczby cetanowej.

[17] PN-86/C-04062 Przetwory naftowe. oznaczanie ciepła spalania paliw ciekłych w bombie kalometrycznej i obliczanie wartości opałowej.

[18] CFR Engines Inc. www.cfrengines.com

[19] Thermo Fisher Scientific www.thermofisher.com

[20] Support for Wikiwand Website \& Extensions www.wikiwand.com 